\title{
Parkinsonism and dystonia in central pontine and extrapontine myelinolysis
}

\author{
A Seiser, S Schwarz, M M Aichinger-Steiner, G Funk, P Schnider, M Brainin
}

\begin{abstract}
Parkinsonism as well as dystonic signs are rarely seen in central pontine myelinolysis and extrapontine myelinolysis. A 51 year old woman developed central pontine myelinolysis and extrapontine myelinolysis with parkinsonism after severe vomiting which followed alcohol and drug intake, even though marked hyponatraemia had been corrected gradually over six days. Parkinsonism resolved four months after onset, but she then exhibited persistent retrocollis, spasmodic dysphonia, and focal dystonia of her left hand. Although the medical literature documents three similar patients, this patient is different as dystonic symptoms only developed four months after parkinsonian signs had resolved. (F Neurol Neurosurg Psychiatry 1998;65:119-121)
\end{abstract}

Keywords: central pontine myelinolysis; extrapontine myelinolysis; parkinsonism; dystonia

Central pontine myelinolysis is a well defined syndrome characterised by various degrees of

Center for

Postgraduate Studies

in Neuroscience,

Danube University,

Krems, Austria, and

Department of

Neurology,

Landesnervenklinik

Klosterneuburg-

Gugging, Austria

A Seiser

S Schwarz

M M Aichinger- Steiner

G Funk

M Brainin

Department of

Neurology, University of Vienna, Austria

P Schnider

Correspondence to: Dr Andreas Seiser, Department of Neurology, Landesnervenklinik Gugging Hauptstraße 2, A-3400 Klosterneuburg, Austria. Telephone 00432243401 371; fax 00432243401338

Received 21 August 1997 and in revised form 5

November 1997

Accepted 11 November 1997 thalamus. sequel of rapid correction of electrolyte disturbances, hyponatraemia in particular. In more severe cases, additional demyelination may occur in extrapontine locations, giving rise to parkinsonian signs and symptoms. Tomita et al recently reported on a patient with extrapontine myelinolysis, exhibiting symptoms of parkinsonism and dystonia in his fingers. ${ }^{1}$ Here we report a case in which parkinsonism and dystonia occurred sequentially within a period of four months and speculate that preclinical damage due to regular alcohol intake might have predisposed our patient to develop dystonic signs only after parkinsonism had subsided.

\section{Case report}

A 51 year old female patient with a history of repeated alcohol and drug misuse was admitted with severe and persisting vomiting after alcohol and drug intake. She became increasingly weak and drowsy and was only able to take a few assisted steps. Gastroscopy showed haemorrhagic gastritis and duodenitis. The admission values for serum sodium, chloride, and potassium were $93 \mathrm{mmol} / 1,58 \mathrm{mmol} / \mathrm{l}$, and

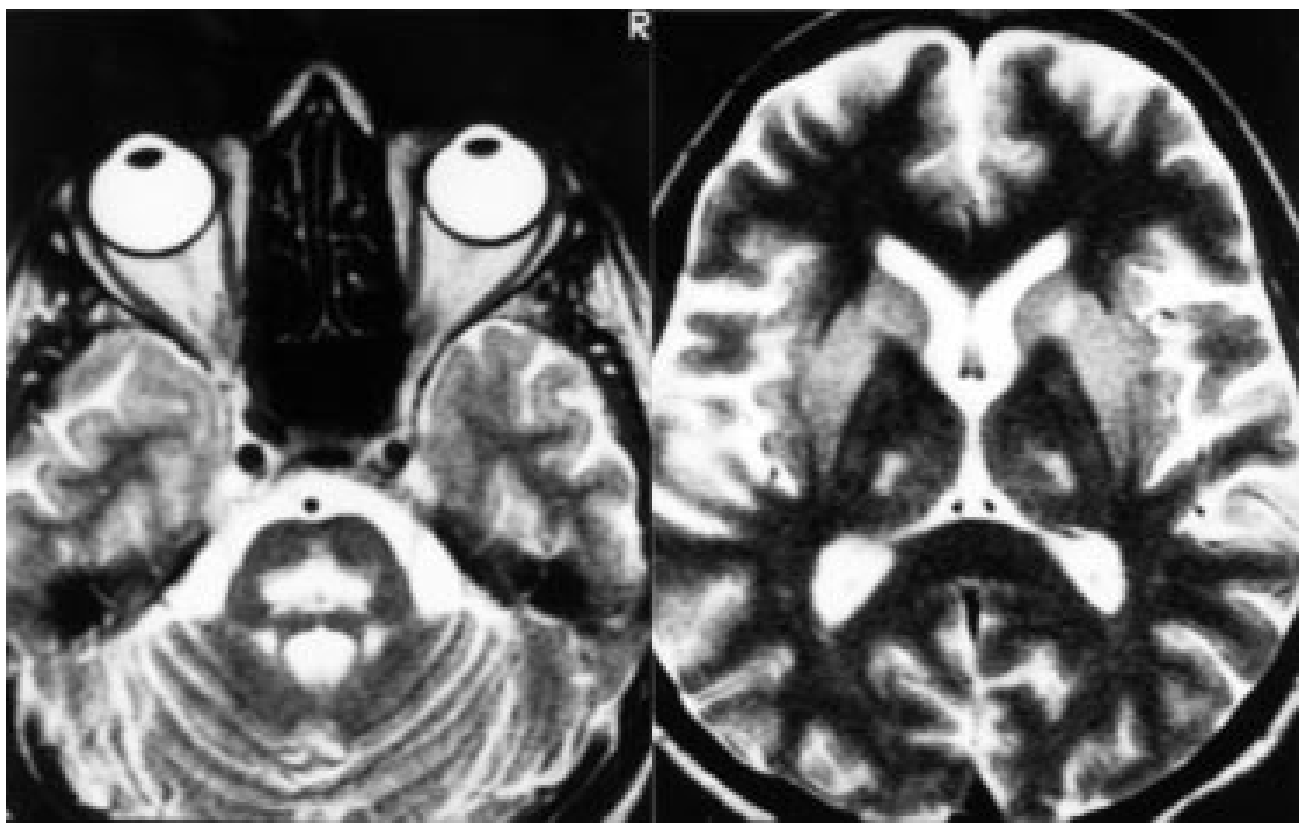

T2 weighted images show a symmetric signal increase in the central pons region, putamen, caput nuclei caudati, and lateral 
Cases of parkinsonian, dystonia, and both after extrapontine myelinolysis

\begin{tabular}{|c|c|c|}
\hline Reference & $n$ & Prominent clinical signs \\
\hline \multicolumn{3}{|l|}{ Parkinsonian: } \\
\hline Stam et $a l^{8}$ & 1 & Tremor, mask-like facial expression \\
\hline Dickoff $e t a l^{5}$ & 1 & $\begin{array}{l}\text { Rest tremor, cogwheel rigidity facial hypomimia, dysphagia, } \\
\text { bradykinesia, retropulsion }\end{array}$ \\
\hline Kurlan et $a l^{6}$ & 1 & Akinetic-rigid features, dysarthria dysphagia \\
\hline Tinker et $a l^{9}$ & 1 & $\begin{array}{l}\text { Impassive face, bradykinesia, rest tremor, cogwheel rigidity, } \\
\text { parkinsonian gait }\end{array}$ \\
\hline Maraganore $e t a l^{7}$ & 1 & Slow resting tremor, parkinsonian gait \\
\hline Sadeh et al ${ }^{4}$ & 1 & $\begin{array}{l}\text { Facial hypomimia, dysarthria, hypokinesia and bradykinesia, resting } \\
\text { tremor, cogwheel rigidity }\end{array}$ \\
\hline \multicolumn{3}{|r|}{$x^{2}$} \\
\hline Grafton et al ${ }^{10}$ & 1 & Focal action dystonia, dysarthria \\
\hline Kurlan et $a l^{6}$ & 1 & Dystonia (limb, trunk, orolingual) \\
\hline Thompson et al ${ }^{11}$ & 1 & Mobile dystonic posturing, wide based gait, dysarthria (2a) \\
\hline Tison et al ${ }^{12}$ & 1 & Generalised dystonia, choreoathetosis, dystonic posturing \\
\hline Maraganore $e t a l^{7}$ & 2 & Generalised action dystonia, athetoid movements \\
\hline \multicolumn{3}{|c|}{ Parkinsonian and dystonia: } \\
\hline Kurlan $e t a l^{6}$ & 1 & Dystonia, akinetic-rigid features \\
\hline Niwa et $a l^{13}$ & 1 & Dystonia and rigidity \\
\hline Tomita et $a l^{1}$ & 1 & $\begin{array}{l}\text { Mask like face, bradykinesia, difficulties protruding the tongue, } \\
\text { dysarthria, parkinsonian posture finger dystonia }\end{array}$ \\
\hline
\end{tabular}

$2.9 \mathrm{mmol} / \mathrm{l}$, respectively. The electrolytic indices were gradually corrected over the subsequent six days using intravenous physiological saline solution under permanent cardiac monitoring. She then became markedly slowed but was fully oriented and of normal intelligence and general knowledge. However, recent memory and ability to learn were impaired. She exhibited cogwheel rigidity of all four limbs, bradykinesia, facial hypomimia, monotonous speech, and parkinsonian gait with associated retropulsion. Intermittent action myoclonus was seen. The deep tendon reflexes were brisk with bilateral extensor plantar responses. The grasp reflex was elicited bilaterally but there was no sensorimotor weakness, only slight dysarthria.

A low dose levodopa/benserazide therapy was started. The parkinsonian signs disappeared. However, an examination four months after admission showed that she had developed marked retrocollis, an oromandibular dystonia with difficulties in opening her mouth and protruding her tongue, and severe dysphagia which required transient feeding through a nasogastric tube, as well as spasmodic dysphonia and focal dystonia of her left arm with severe functional impairment. Subsequently, the dysphagia, retrocollis, and oromandibular dystonia improved. However, the focal dystonia of the right arm and the spasmodic dysphonia were still present during a follow up period of 20 months, despite treatment with tiaprid and perphenazine.

Brain MRI showed a signal increase in the central pons on T2 weighted images but also bilateral hyperintense areas within the putamen, caput nuclei caudati, and lateral thalamus (figure). Subsequent control images made up to six months after the onset of the condition showed a marked decrease of these signal intensities. An EEG disclosed diffuse slow background activity and bilateral theta and delta activity which improved gradually during the subsequent months. Brain stem auditory evoked potentials measured eight months after onset of disease were normal, as were CSF and a $\beta$-CIT SPECT examination of the brain.

\section{Discussion}

Central pontine myelinolysis results from rapid correction of hyponatraemia and generally presents with tetraparesis and various degrees of brain stem dysfunction such as pontine dysfunction, pseudobulbar palsy, and, occasionally, locked in syndrome. ${ }^{2}$ Extrapontine myelinolysis occurs in about $10 \%$ of patients with central pontine myelinolysis. ${ }^{3}$ Extrapyramidal symptoms are, however, rarely seen, as they are often masked by involvement of the pyramidal tract and brain stem. ${ }^{4}$ To date, six such patients with parkinsonism have been described. The table shows the symptoms. ${ }^{4-9}$ Most patients responded to dopaminergic therapy. Brain MRI disclosed hyperintense lesions in the striatum, especially in the putamen and the caput nuclei caudati. Dystonia was reported in six patients (table). $.^{6-7} 10-12$ The onset was delayed in most patients and response to treatment was variable. In no patients did the pathological changes visualised on MRI fully explain the dystonic symptoms. Three further patients developed a combination of simultaneous parkinsonian and dystonic symptoms (table). ${ }^{16}{ }^{13}$ However, our patient is the first to develop dystonic symptoms within four months and only after complete regression of parkinsonism had occurred. In addition, it is remarkable that central pontine myelinolysis developed despite the relatively slow and delayed correction of hyponatraemia. It seems feasible that the rather low initial serum electrolyte concentrations, as well as preexisting alcohol and drug misuse increased the risk of myelin damage. ${ }^{14}$

We thank Dr Rosemary Ferris for critically reading the manuscript.

1 Tomita I, Satoh H, Satoh A, et al. Extrapontine myelinolysis presenting with parkinsonism as a sequel of rapid correction of hyponatraemia. 7 Neurol Neurosurg Psychiatry 1997;60:422-3.

2 Adams RD, Victor M, Mancall EL. Central pontine myelinolysis. Arch Neurol Psychiatry 1959;81:154-72

3 Wright DG, Laureno R, Victor M. Pontine and extrapontine Wright DG, Laureno R, Victor M. Pon
myelinolysis. Brain 1979;102:361-85.

myelinolysis. Brain 1979;102:361-85.
4 Sadeh M, Goldhammer J. Extrapyramidal syndrome responSadeh M, Goldhammer J. Extrapyramidal syndrome respon-
sive to dopaminergic treatment following recovery from central pontine myelinolysis. Eur Neurol 1993;33:48-50. 
5 Dickoff DJ, Raps M, Yahr MD. Striatal syndrome following hyponatraemia and first rapid correction. Arch Neurol 1988;45:112-4.

6 Kurlan R, Schoulson I. Dystonia and akinetc rigid features in central pontine myelinolysis [abstract]. Ann Neurol 1989;26:141

7 Maraganore DM, Folger WN, Swanson JW, et al. Movement disorders as a sequelae of central pontine myelinolysis. report of three cases. Mov Disord 1992;7:142-8.

8 Stam J, Van Oers JHJ, Verbetten B. Recovery after central pontine myelinolysis. F Neurol 1984;231:52-3.

9 Tinker R, Anderson MG, Anand P, et al. Pontine myelinolysis presenting with acute parkinsonism as a sequel of corrected hyponatriemia. $\mathcal{f}$ Neurol Neurosurg Psychiatry 1990;53:87-8.

10 Grafton FT, Bahls FH, Bell KR. Aquired focal dystonia fol- lowing recovery from central pontine myelinolysis. $\mathcal{F}$ Neurol Neurosurg Psychiatry 1988;51:1354-5.

11 Thompson PD, Miller D, Gledhill RF, et al. Magnetic resonance imaging in central pontine myelinolysis. $f$ Neurol Neurosurg Psychiatry 1989;52:675-77.

12 Tison FX, Ferrer X, Julien J. Delayed onset movement disorders as a complication of central pontine myelinolysis. Mov Disord 1991;6:171-3.

13 Niwa K, Matsushima K, Yamamoto M, et al. A case of extrapontine myelinolysis demonstrated on MRI. Clin Neurol 1995;31:327-30.

14 Soupart A, Decaux G. Therapeutic recommendations for management of severe hyponatremia: current concepts on pathogenesis and prevention of neurologic complications. Clin Nephrol 1996;46:149-69.

\section{Fournal of Neurology Neurosurgery and Psychiatry - http://www.jnnp.com}

Visitors to the world wide web can now access the fournal of Neurology Neurosurgery and Psychiatry either through the BMJ Publishing Group's home page (http://www.bmjpg.com) or directly by using its individual URL (http://www.jnnp.com). There they will find the following:

- Current contents list for the journal

- Contents lists of previous issues

- Members of the editorial board

- Subscribers' information

- Instructions for authors

- Details of reprint services.

A hotlink gives access to:

- BMJ Publishing Group home page

- British Medical Association web site

- Online books catalogue

- BMJ Publishing Group books.

The web site is at a preliminary stage and there are plans to develop it into a more sophisticated site. Suggestions from visitors about features they would like to see are welcomed. They can be left via the opening page of the BMJ Publishing Group site or, alternatively, via the journal page, through "about this site". 